\title{
Study of Xanthate Decomposition in Aqueous Solutions
}

Yang Shen ${ }^{1}$, D. R. Nagaraj ${ }^{2}$, Raymond Farinato ${ }^{2}$, and Ponisseril Somasundaran ${ }^{1}$

${ }^{1}$ Earth and Environmental Engineering, Columbia University, New York, NY 10027

${ }^{2}$ Mining Department, Cytec Industries, Stamford, CT 06902

\section{Abstract}

Xanthate is one of the commonly used collectors in froth flotation beneficiation of sulfide ores. It could-decomposes and generates toxic compounds such as carbon disulfide $\left(\mathrm{CS}_{2}\right)$ which is a concern in the mining industry. A vast body of literature exists for studies on xanthate/mineral interactions, but xanthate decomposition under various conditions (e.g., in solutions or flotation pulps) is not fully understood. We have undertaken detailed studies to fill this knowledge gap, and this paper shows our study of the xanthate decomposition in aqueous solutions in the absence of minerals. This condition has not been appropriately examined by past researchers, while decomposition under this condition is used as control to other complicated ones (e.g., in flotation pulps). A GC-MS based method was developed to directly measure the decomposition products in the gas phase. Decomposition kinetics was then established based on the generation of $\mathrm{CS}_{2}$. Decomposition followed the first order kinetics, and the rate constant for Sodium iso-Butyl Xanthate (SIBX) at neutral $\mathrm{pH}$ level was determined to be $9.3 \times 10^{-4} \mathrm{~h}^{-1}$ at $25_{-}^{\circ} \mathrm{C}$, $1.7 \times 10^{-2} \mathrm{~h}^{-1}$ at $50_{-}^{\circ} \mathrm{C}$ and $1.3 \times 10^{-1} \mathrm{~h}^{-1}$ at $70_{-}^{\circ} \mathrm{C}$. The effect of $\mathrm{pH}$ on decomposition behavior was examined in the $\mathrm{pH}$ range of 1.5 to 12.5 . We determined experimentally a maximum in the extent of decomposition-extent as a function of $\mathrm{pH}$, which was predicted theoretically in literature. A mechanism involving multiple reactions that occurred in parallel or in sequence sequentially along with the decomposition was proposed to explain the observed change of

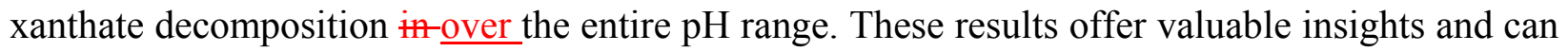
serve as the basis to mitigate the detrimental effects of xanthate decomposition in plant 
25 operations, for example, by modifying plant parameters to reduce xanthate decomposition

26 without sacrificing its performance.

27 Key Words:

28 Xanthate, Decomposition in Aqueous Solutions, Decomposition Rate, Carbon Disulfide

29

30

31

32

33

34

35

36

37

38

39

40

41

42

43

44

45 


\section{Introduction}

Xanthate (or alkyl dithiocarbonate, $\mathrm{R}-\mathrm{OCS}_{2}^{-}$) is a widely used collector in the flotation

beneficiation of base metal (such as copper, nickel, zinc, and iron) sulfides and precious metal

49 ores, besides its role as a reactant or additive in pesticide, rubber, cellulose, and pharmaceutical

50 industries since the $18^{\text {th }}$ century (Spottiswod and Kelly, 1982; Wills, 2006). It is also known to

51 hydrolyze in aqueous solutions and flotation pulps to continually generate toxic species such as

52 carbon disulfide $\left(\mathrm{CS}_{2}\right)$, which can accumulate in the flotation plants and thus present a

53 significant hazard on the safety, health and environment (SHE). In recognition of the potential

54 health impacts from the hazardous gases accumulating in the enclosed infrastructures and the

55 chronic exposure to the decomposition products, regulatory bodies are limiting the permissible

56 level of $\mathrm{CS}_{2}$ in the ambient atmosphere. The permissible limit for $\mathrm{CS}_{2}$ release has decreased from

57 10ppm to $1 \mathrm{ppm}$ in the US and Canada (OSHA). Measures need to be taken to apply xanthate in a

58 benign and sustainable manner in the flotation operations, reducing the negative SHE impacts.

59 This requires a detailed understanding of the decomposition behavior of xanthate. While extensive studies have been conducted in the past eight decades to understand the interactions

61 between xanthate and sulfide minerals as well as precious metals (Healy, 1984; Poling, 1976;

62 Salamy and Nixon, 1953; Woods, 1976, 1984, 1996), the decomposition behavior remains

63 poorly understood. To develop a more complete understanding of xanthate decomposition, we

64 have taken steady investigations towards examining the decomposition behavior of xanthates

65 under various conditions (e.g., in aqueous solutions in the absence of minerals and in ore pulps

66 under flotation conditions). This paper focuses on Sodium iso-Butyl Xanthate (SIBX)

67 decomposition in aqueous solutions in the absence of minerals, which is a control for other 68 conditions. 
Decomposition is defined as the breakup of the xanthate anion into pieces fragments

70 (such as carbon disulfide or carbonyl sulfide). Dimerization or oxidation of xanthate to

71 dixanthogen $\left(\left(\mathrm{R}-\mathrm{OCS}_{2}\right)_{2}\right)$ is not included in the definition of decomposition, though it was

72 included in some studies (Rao, 1971). There are a few published studies on xanthate

73 decomposition in aqueous solutions in the absence of minerals (Rao, 1971; Report, 2000). In

74 these studies, researchers applied a similar method called Stopped Flow Technique (SFT)

75 developed by Tornell to investigate the decomposition (Tornell, 1966a, b, 1967). SFT employs

76 UV-vis spectroscopy as the primary technique to track the decrease of xanthate in the aqueous

77 solutions. The amounts of decomposition products generated were derived from the relationship

78 of residual xanthate content as a function of time. This method suffered from several limitations

79 in spite of adopting a meticulous protocol for preparing and measuring the concentrations of

80 solution species. For example, decomposition products in the gas phase could not be identified

81 directly and $\mathrm{CS}_{2}$ had to be assumed to be the only product in the gas phase. The UV-vis band

82 assignments for xanthate and its relevant compounds (such as xanthic acid or dixanthogen) were

83 not unanimously agreed upon. SFT was not suitable for heterogeneous solutions containing

84 minerals (i.e., in ore pulp of flotation operationflotation pulp). Last but not least, the decrease of xanthate in solution might not be solely due to decomposition. Despite $\theta$ f the limitations of SFT, 86 certain key findings have been reported.

Iwasaki et al. (Iwasaki and Cooke, 1958), Finkelstein (Finkelstein, 1967), and Tipman et al. (Tipman and Leja, 1975) indicated that oxygen did not affect decomposition in acidic and alkaline solutions. It This permits studying xanthate decomposition under ambient conditions; i.e. exposure to air. Researchers have examined the impact of $\mathrm{pH}$ on decomposition more than that 91 of any other factor. It was generally believed that decomposition is greater under acidic 
92 conditions than under alkaline conditions. However, in alkaline solutions, multiple reactions

93 were associated with the xanthate decomposition process, in contrast to the dominance of a 94 single step reaction in acidic solutions. For example, under acidic conditions, xanthate 95 decomposes to $\mathrm{CS}_{2}$, whereas under alkaline conditions it also forms dixanthogen (Pomianowski and Leja, 1963), perxanthate (Pomianowski and Leja, 1963; Sun and Forsling, 1997), monothio-

97 and dithio-carbonates (Philip and Fichte, 1960), and trithiocarbonate (Report, 2000). With respect to kinetics, xanthate decomposition was reported to follow a first order law regardless of pH (Ballard et al., 1954; Finkelstein, 1967, 1977; Iwasaki and Cooke, 1958, 1959, 1964; Klein et al., 1960; Majima, 1961). Multiple reactions in parallel or in sequence-sequentially (Report, 2000) 101 accompanied the decomposition reaction, but the $\mathrm{CS}_{2}$ generation was still found to obey the first 102 order kinetics (Finkelstein, 1967, 1977). Nevertheless, it is unclear as to whether the 103 decomposition reaction should be unimolecular (Ballard et al., 1954; Iwasaki and Cooke, 1958, 104 1959, 1964; Klein et al., 1960) or bimolecular (Majima, 1961). It remains uncertain as to whether 105 there existed exists a maximum decomposition extent as a function of $\mathrm{pH}$. Ballard et al. (Ballard 106 et al., 1954), Klein et al. (Klein et al., 1960) and Iwasaki et al. (Iwasaki and Cooke, 1964) 107 proposed such a maximum when $\mathrm{pH}$ reached a certain low level while others did not (Iwasaki 108 and Cooke, 1958, 1959). Under alkaline conditions, Tipman et al. (Tipman and Leja, 1975) found that decomposition remained almost unchanged with $\mathrm{pH}$, while Finkelstein (Finkelstein, 1967, 1977) observed that it still decreased.

Although studies were found on xanthate decomposition in the literature, they are limited 112 and with provide inadequate methods and conflicting results. As explained above, the 113 decomposition was not fully understood in aqueous solutions in the absence of minerals. It is, 114 however, necessary to have sufficient knowledge of decomposition under this control condition 
115 so as to elucidate this behavior under other conditions. This paper reports the study of SIBX

116 decomposition in aqueous solutions in the absence of minerals with a new method markedly

117 different from the SFT. A The method was adopted to analyze the decomposition products in the

118 gas phase directly by GC-MS (Gas Chromatography-Mass Spectroscopy). SIBX decomposition

119 was examined as a function of time, xanthate concentration, and $\mathrm{pH}$. One goal of the study was

120 to determine whether the decomposition kinetics could be assessed by analyzing the

121 decomposition products in the gas phase. A second goal was to examine whether or not a

122 maximum decomposition extent exists. A third goal was to discuss and propose probable parallel

123 and sequential reactions that may be responsible for the decomposition behavior across the acid-

124 to-alkaline $\mathrm{pH}$ range.

126 Experimental

$127 \quad$ Materials

Sodium iso-Butyl Xanthate $\left(\mathrm{SIBX},\left(\mathrm{CH}_{2}\right)_{2} \mathrm{CHCH}_{2} \mathrm{OCS}_{2} \mathrm{Na}\right)$ with $\geq 99 \%$ purity was

129 obtained from Cytec Industries. Fresh xanthate solutions were prepared right before each

130 experiment. Reagent Grade $\mathrm{CS}_{2}$ with $\geq 99.9 \%$ purity was purchased from Fisher Scientific. A

131 series of standard solutions of $\mathrm{CS}_{2}$ with different concentrations in distilled water were prepared

132 to develop a calibration curve for the estimation of the $\mathrm{CS}_{2}$ generated upon SIBX decomposition.

133 Water used was triple distilled $\left(\mathrm{EC}=1.5 \mu \Omega^{-1}\right)$. Reagent Grade $\mathrm{HCl}$ and $\mathrm{NaOH}$, obtained from

134 Sigma Aldrich, were used to regulate the $\mathrm{pH}$ levels of the SIBX solutions. 

in the absence of minerals or ore pulps under flotation conditions) is shown in Figure 1.

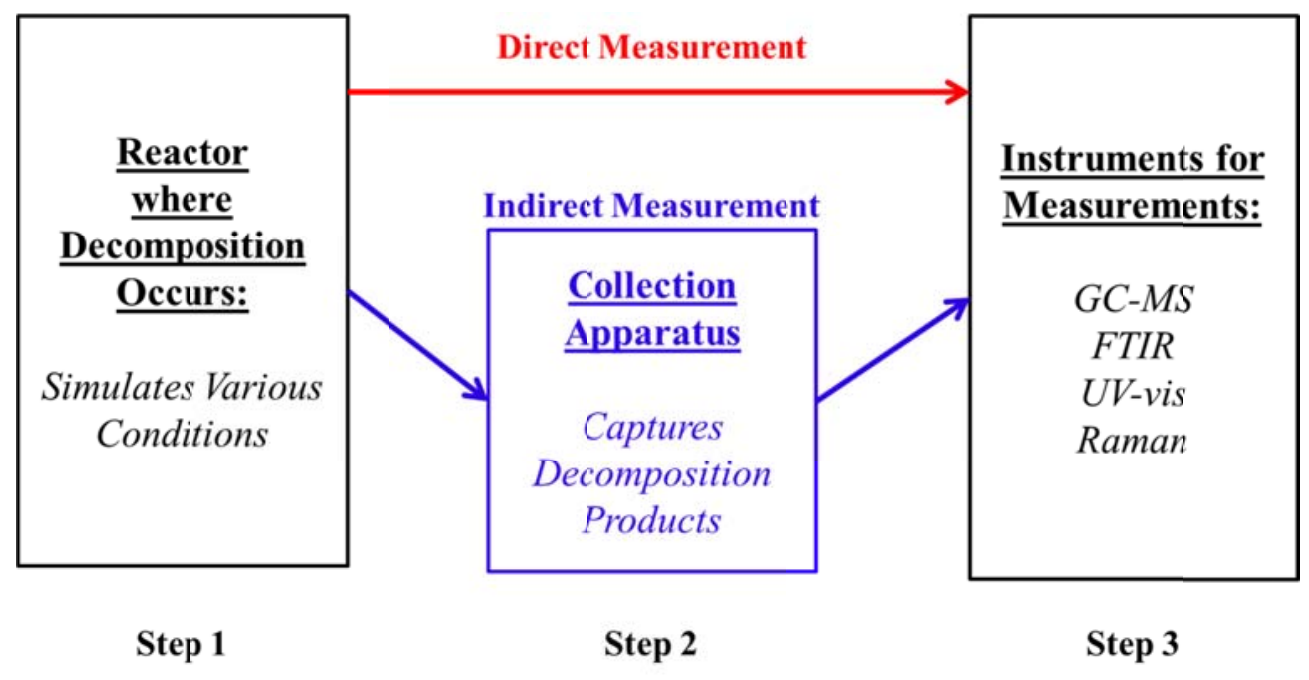

Figure 1. General scheme for measuring decomposition products

144 accumulate decomposition products. The impact of factors can be examined by modifying the 145 conditions in the reactor. The decomposition products in different phases can be either directly 146 sent to the instrument for measurement, or collected and then subsequently sent for measurement.

147 The instruments for measuring decomposition products in various phases include GC-MS, FTIR, 148 UV-vis, and Raman. 
Based on the scheme in Figure 1, the experimental procedure to study decomposition in

150 aqueous solution in the absence of minerals is shown in Figure 2. The reactor is a 10_ml glass vial that can be crimped with an aluminum cap lined with a silicone septum. A Teflon film is deposited at the bottom of septum facing inside the vial. In each test, stock SIBX solution and distilled water were introduced into the vial to obtain a 1_ml SIBX solution at a desired concentration. The temperature was controlled by placing the vial in an incubator. 1 ml of the 9 $\mathrm{ml}$ headspace was extracted and transferred to the GC-MS for measurement after a given time. Each vial was used for only one measurement and the above procedure was repeated to prepare another vial for a new measurement.

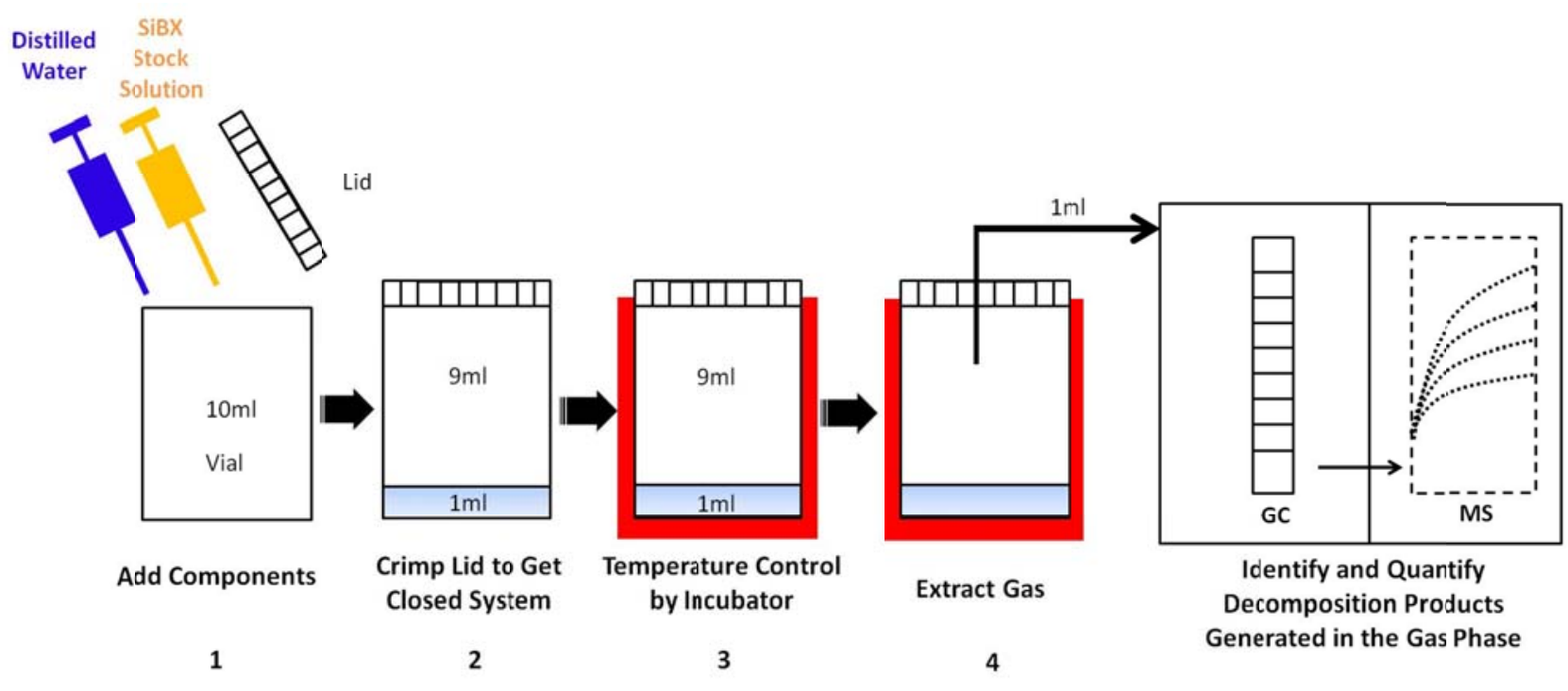

Figure 2. Experimental scheme for measuring decomposition products in the gas phase 
164 for the GC-MS is capable of extracting and transferring the sample in the headspace from a

\begin{tabular}{|c|c|c|c|c|}
\hline Variable & Time $^{\wedge}$ (Hours) & $\mathrm{pH}^{*}$ & $\begin{array}{c}\text { SIBX Concentration } \\
(\mathrm{wt} . \%)^{\#}\end{array}$ & $\begin{array}{c}\text { Temperature } \\
\left({ }^{\circ} \mathrm{C}\right)\end{array}$ \\
\hline Time & $0.5,1,2,3,4,5,6$, & $\mathrm{Ca} .6 .8$ & 0.05 & 25,50 and 70 \\
\hline SIBX & $8,10,12,14,24$ & & & 50 \\
Concentration & 2 & Fixed at 7 & $0.05,0.1,0.25,0.5$, & \\
\hline $\mathrm{pH}$ & 2 & 1.5 to 12.5 & $0.75,1$ & 25 \\
\hline
\end{tabular}
sealed vial to the column. There is an incubator as part of the MPS that can hold the vial at a chosen temperature before the headspace is extracted. This sampler enables direct measurement of the SIBX decomposition products generated in the gas phase. The model of GC-MS used in this study was Agilent 6890GC/5973MS. MPS was from Gerstel. The column was DB-5MS (30 $\mathrm{m}$ length, $0.25 \mathrm{~mm}$ I.D., and $0.25 \_\mu \mathrm{m}$ film thickness). The temperature program for the column was $35_{-}^{\circ} \mathrm{C}(2 \min )+15_{-}^{\circ} \mathrm{C} / \min$ to $120_{-}^{\circ} \mathrm{C}+30_{-}^{\circ} \mathrm{C} / \min$ to $300_{-}^{\circ} \mathrm{C}$. Other key parameters of the GC-MS during measurements were: split ratio 5:1, injection port temperature $200_{-}^{\circ} \mathrm{C}$, and flow rate $1 \_\mathrm{ml} / \mathrm{min}$. Three variables, namely decomposition time, initial SIBX concentration, and $\mathrm{pH}$, were examined and Table 1 summarizes the details of the experimental program.

^Counted from when the vial was sealed until the headspace was extracted for GC/MS measurement.

*Represents the initial $\mathrm{pH}$ of the solution.

${ }^{\#}$ Initial concentration of SIBX solution. 
181

\section{5}

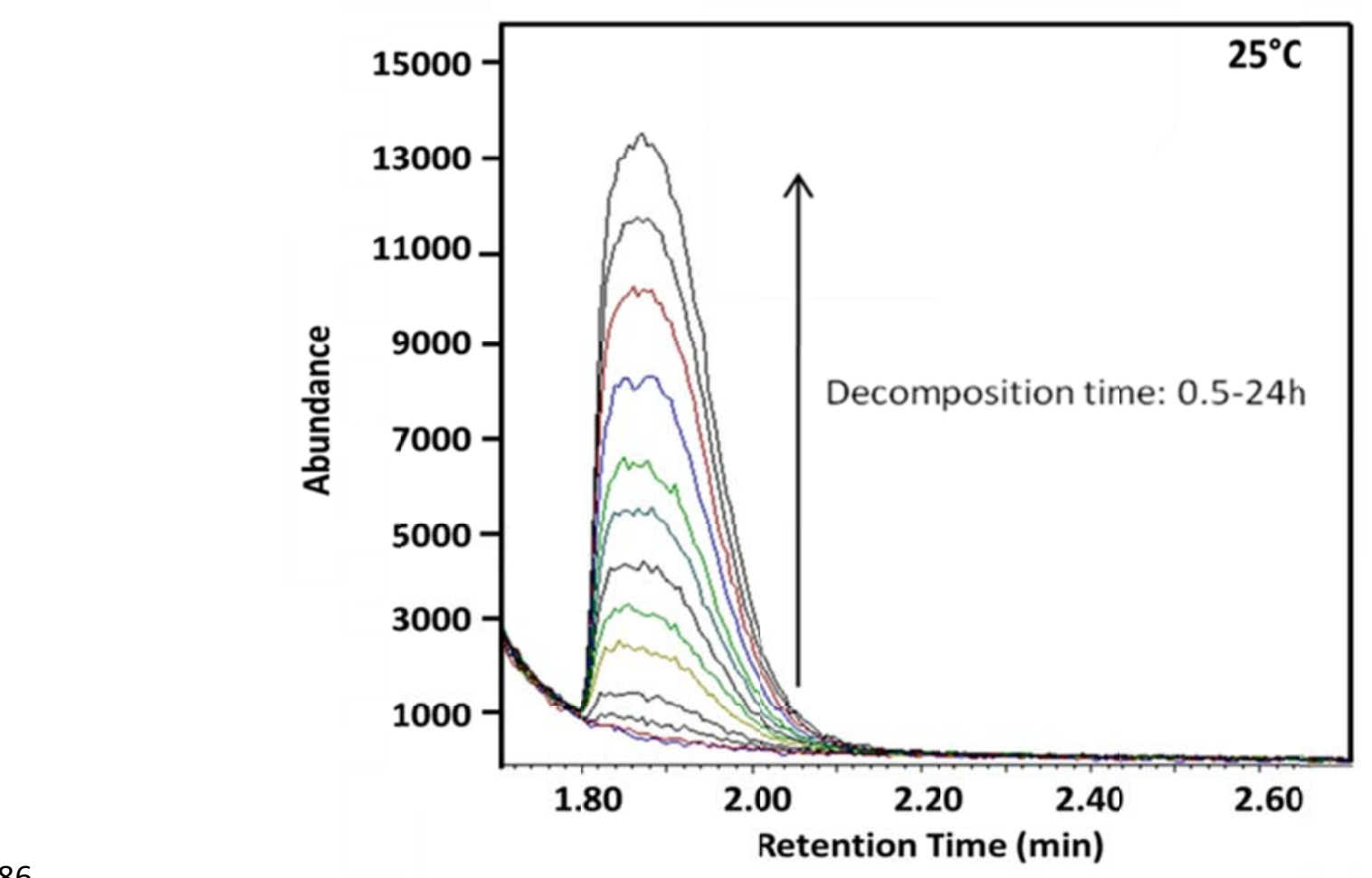

the gas phase as a function of time (with each chromatogram provide information about the decomposition products after a certain decomposition interval).

\section{Results and Discussion}


192 The decomposition kinetics could thus be studied by determining the amount of $\mathrm{CS}_{2}$ as a function 193 of time. Evaluation of decomposition kinetics based on $\mathrm{CS}_{2}$ was consistent with that reported in 194 literature, which assumed that $\mathrm{CS}_{2}$ was the only decomposition product from xanthate.

\section{Decomposition vs. Time} were estimated from the peak area. Figure 4 shows the amount of $\mathrm{CS}_{2}$ from SIBX decomposition

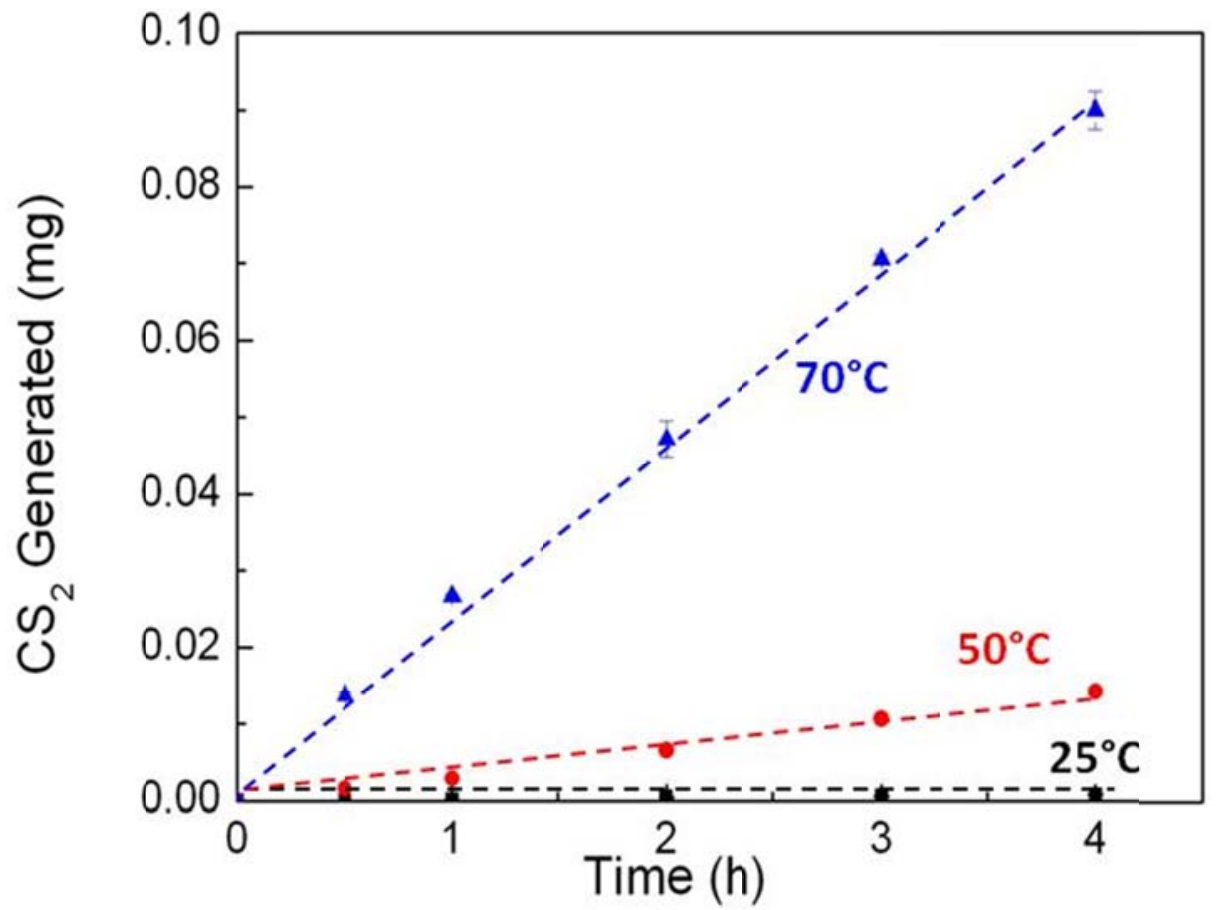


Below the calculation for the decomposition rate constant based on the $\mathrm{CS}_{2}$ generated from SIBX decomposition is demonstrated. The SIBX decomposition for the generation of $\mathrm{CS}_{2}$ can be written as:

$$
\left(\mathrm{CH}_{3}\right)_{2} \mathrm{CHCH}_{2} \mathrm{OCS}_{2} \mathrm{Na}+\mathrm{H}_{2} \mathrm{O} \Leftrightarrow \mathrm{CS}_{2}+\left(\mathrm{CH}_{3}\right)_{2} \mathrm{CHCH}_{2} \mathrm{OH}+\mathrm{NaOH}
$$

Controversy exists with respect to whether the decomposition reaction should be unimolecular (i.e., xanthate and water first form xanthic acid which then decomposes) or bimolecular (i.e., shown by Eq.1). We believe that the bi-molecular reaction is more reasonable. This is because xanthic acid is a moderately strong acid with $p \mathrm{Ka}=2.23$ for butyl xanthic acid (Report, 2000), so under the alkaline, neutral, and weakly acidic conditions, xanthic acid dissociates. Moreover, it was found that molecular xanthic acid was stable in aprotic solvents, therefore there is no reason why it should decompose spontaneously in water (Report, 2000).

The rate of generation of $\mathrm{CS}_{2}$ can be expressed as:

$$
\frac{\mathrm{d}\left[\mathrm{CS}_{2}\right]}{\mathrm{dt}}=-\frac{\mathrm{d}[\mathrm{SIBX}]}{\mathrm{dt}}=\mathrm{k}_{1}[\mathrm{SIBX}]-\mathrm{k}_{2}\left[\left(\mathrm{CH}_{3}\right)_{2} \mathrm{CHCH}_{2} \mathrm{OH}\right]\left[\mathrm{CS}_{2}\right][\mathrm{NaOH}]
$$
wherein $\left[\mathrm{CS}_{2}\right],[\mathrm{SiBX}],\left[\left(\mathrm{CH}_{3}\right)_{2} \mathrm{CHCH}_{2} \mathrm{OH}\right]$, and $[\mathrm{NaOH}]$ are the concentrations of $\mathrm{CS}_{2}$, SIBX, iso-Butanol, and $\mathrm{NaOH}$ in solution, respectively; $k_{1}$ and $k_{2}$ are the reaction rate constants for the forward and reverse directions of Eq. 1. 
As duration for the decomposition was short, the amount of $\mathrm{CS}_{2}$ generated was very low

221 (seen from Figure 4) and a much smaller amount relative to that of SIBX. Therefore, the reverse

222 reaction can be neglected. The final rate equation for the generation of $\mathrm{CS}_{2}$ can be written as:

$$
\frac{\mathrm{d}\left[\mathrm{CS}_{2}\right]}{\mathrm{dt}}=-\frac{\mathrm{d}[\mathrm{SIBX}]}{\mathrm{dt}}=\mathrm{k}_{1}[\mathrm{SIBX}]
$$

\section{Decomposition vs. Initial SIBX Concentration}

228 Typical concentrations of xanthates used in flotation are 50-500_ppm, according to the 229 type of ores under flotation beneficiation (Spottiswod and Kelly, 1982; Wills, 2006). In the 230 literature, studies of decomposition also encompassed a variety of dosages, some of which were 231 higher than the actual amount that is typically used for flotation. Thus, solutions with initial 232 SIBX concentration ranging from 0.05 to $1 \%$ wt. $\%$ were investigated. Figure 5 shows the $\mathrm{CS}_{2}$ 233 generated as a function of the initial SIBX concentration. 


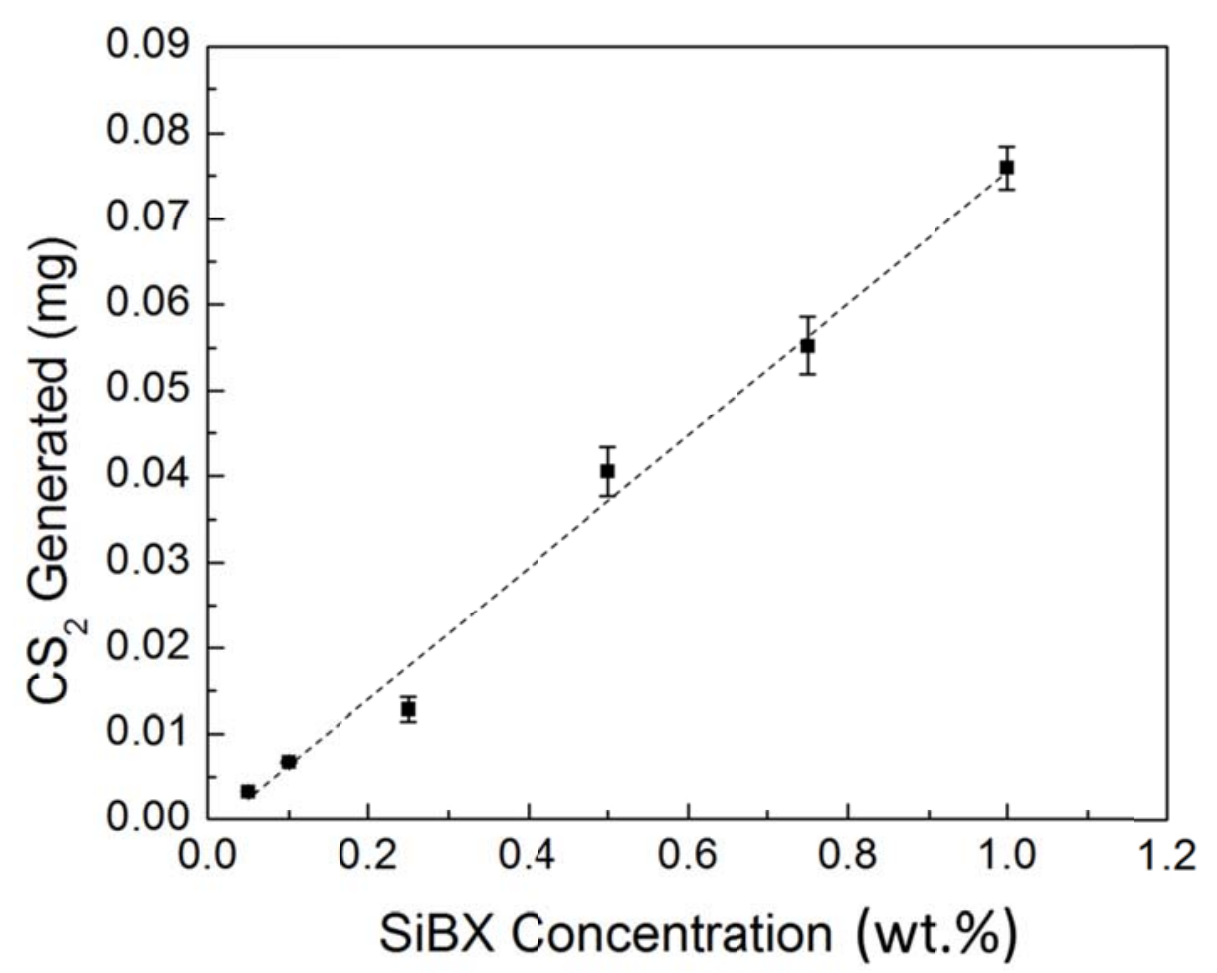

235

236

237

238

239

240

241

242

Decomposition followed the first order rate law, so Eq. 4 could be obtained from Eq. 3:

$\ln [\mathrm{SIBX}]_{\mathrm{t}}=-\mathrm{k}_{1} \mathrm{t}+\ln [\mathrm{SIBX}]_{0}$

$2 h$

A linear relationship was seen from the $\mathrm{CS}_{2}$ generated vs. the initial SIBX concentration, confirming the decomposition to follow the first order kinetics.

\section{Decomposition Kinetics}


concentration in solution, respectively.

247 based on the $\mathrm{CS}_{2}$ in the gas phase:

$$
\ln [\mathrm{SIBX}]_{\mathrm{t}}=\ln \left([\mathrm{SIBX}]_{0}-\frac{172}{76} \mathrm{~m}\left(\mathrm{CS}_{2}\right)_{\mathrm{air}}\right)
$$

wherein $m\left(C S_{2}\right)_{a i r}$ is the mass of $C S_{2}$ in the gas phase. The $C S_{2}$ generated will be partitioned between the solution and gas phases. The partition coefficient of $\mathrm{CS}_{2}$ is difficult to obtain in solutions containing xanthate, as it is continuously decomposing. Thus, the calculation

252 above only accounted for $\mathrm{CS}_{2}$ that ended up in the gas phase-only. $1.7 \times 10^{-2} \pm 2.7 \times 10^{-4} \mathrm{~h}^{-1}$ at $50{ }_{-}^{\circ} \mathrm{C}$ and $1.3 \times 10^{-1} \pm 3.3 \times 10^{-3} \mathrm{~h}^{-1}$ at $70_{-}^{\circ} \mathrm{C}$ for the $0.05 \_\mathrm{wt} . \%$ SIBX solution at $\mathrm{pH}$ 6.8. Compared to the rate constant calculated by previous researchers, we found that it was of the order of $10^{-4} \mathrm{~h}^{-1}$ at $25_{-}^{\circ} \mathrm{C}$ at $\mathrm{pH} 7$ (Finkelstein, 1967, 1977; Tipman and Leja, 257 1975). The value in our case was higher. Four possible causes are listed below to explain the difference:

1) $\mathrm{pH}$ level: slightly different in our study $(\mathrm{pH}=6.8)$ compared to that in literature $(\mathrm{pH}=7)$. solutions to calculate the decomposition rate constant, while we used GC-MS to directly measure

$262 \mathrm{CS}_{2}$ in the gas phase. Early studies using the UV-vis spectroscopy suffered from the issue of 
263 ambiguous assignment of bands to xanthate and its related compounds (such as xanthic acid and 264 dixanthogen), leading to an inaccuracy in the subsequent quantification of the UV-vis bands.

3) Type of xanthates: Ethyl, butyl, and amyl xanthates were used in the past studies, while iso-butyl xanthate was used throughout our study.

4) Approaches used to calculate the rate constant: in prior work a complex decomposition

268

269

270

271

272

273

274

275

276

277

278

279

280

281

282

283

284 pathway was presumed, which combined either the uni- or bi- molecular decomposition reaction with other reactions that xanthate was involved in. In the derivation of rate equations, additional assumptions were made which introduce unknown variables. Consequently, the rate constant could be obtained as long as all the other variables were computed together. This approach, adopted by prior researchers, is rather difficult to evaluate the decomposition kinetics. Moreover, their approach was conducted in a reverse manner because they fit the data to their presumed decomposition pathway. This approach could result in misleading interpretations since a set of data could well fit more than one possible pathway. On the contrary, our approach as shown above calculated the decomposition rate constant directly from our experimental data according to Eq.1. With respect to the multiple reactions (occurring in parallel or sequentially with the decomposition reaction) that could affect decomposition, we attempted to find them by varying solution conditions. For example, a list of the probable reactions that could occur in different $\mathrm{pH}$ ranges is given below.

\section{Assessment of Decomposition at Different pH Levels}

Prior studies discuss the impact of $\mathrm{pH}$ relatively more frequently than any other factor. Although $\mathrm{pH}$ has been acknowledged to affect decomposition significantly, its impact is still not understood adequately. Our study was aimed to examine the impact of $\mathrm{pH}$ over a wider range 
285 compared to other studies in literature that investigated this factor under strictly acidic or alkaline

286 conditions. The $\mathrm{CS}_{2}$ generated measured from the SIBX solutions as a function of $\mathrm{pH}$ between $287 \quad 1.5$ and 12.5 is illustrated in Figure 6.

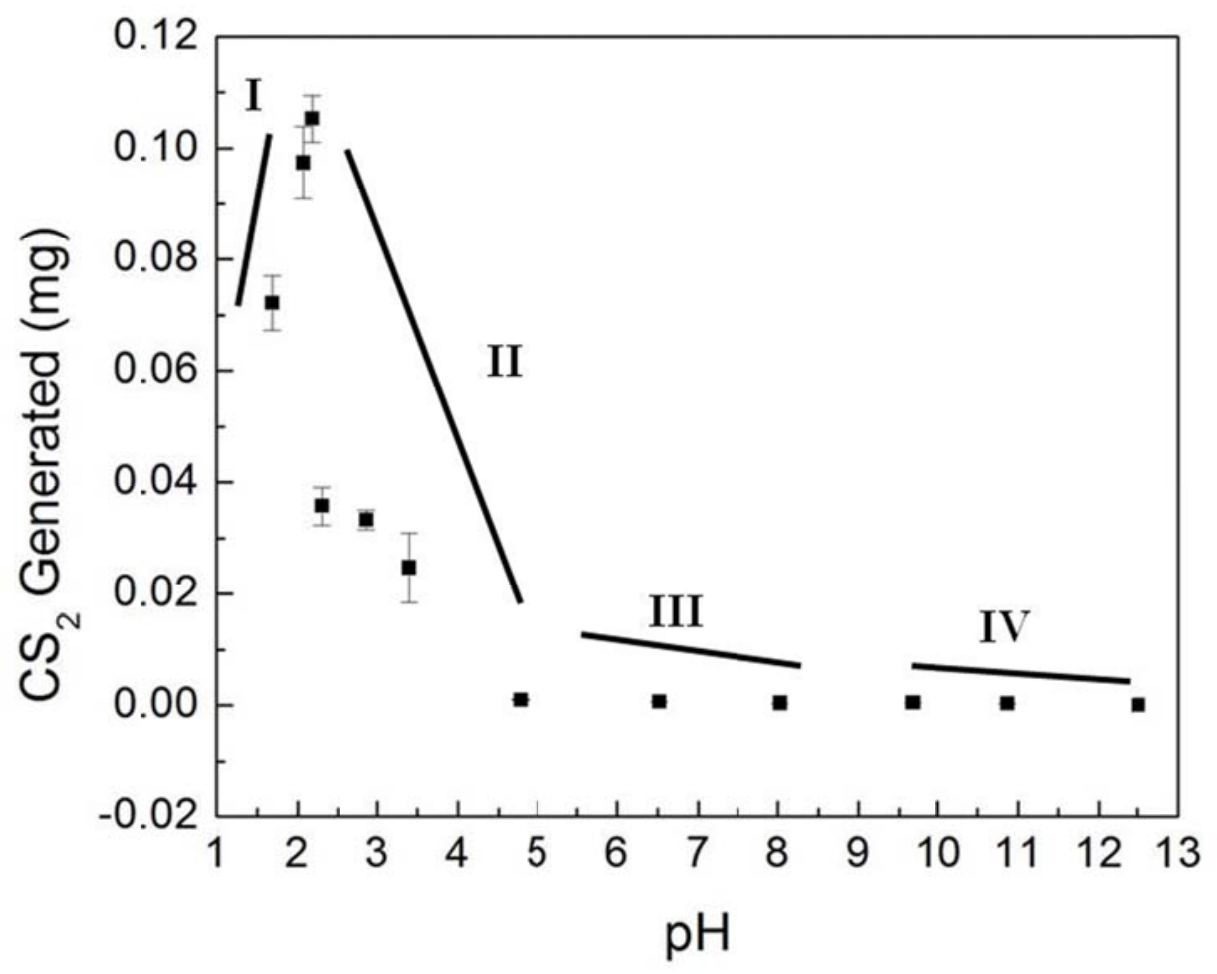

290

Figure 6. Generation of $\mathrm{CS}_{2}$ at different $\mathrm{pHs}$ from 0.05_wt.\% SIBX solution conditions. A maximum decomposition extent was observed at ca. $\mathrm{pH}$ 2.2. This observation was

294 in accord with the findings from several researchers (Ballard et al., 1954; Iwasaki and Cooke, 295 1964; Klein et al., 1960). Notably, while we could confirm the occurrence of this maximum in 296 our study using GC-MS, it could not be reliably observed in SFT using UV-vis spectroscopy. 
$297 \mathrm{CS}_{2}$ generation was lower at $\mathrm{pH}$ levels above this maximum and decreased moderately as $\mathrm{pH}$ 298 continued to increase beyond this. Such a negligible decrease in the $\mathrm{CS}_{2}$ generation at high $\mathrm{pH}$ 299 agreed with Finkelstein's result (Finkelstein, 1967, 1977), in which the decomposition was 300 shown to decrease even though the decrease was minor.

301 In order to understand how decomposition changes vs. pH may have been due to 302 differentthe decomposition mechanisms at different $\mathrm{pH}$ levels, investigating-investigation of the probable parallel or sequential reactions would beis required. However at present we could only reasonably propose the multiple reactions associated in the decomposition process at different pH levels. We elaborate-Before any experimental efforts are taken, these plausible parallel or sequential reactions accompanying the basic decomposition reaction (Eq. 1) are proposed as below:

1. At neutral $\mathrm{pH}$ (Region III) the decomposition followed:

$$
\left(\mathrm{CH}_{3}\right)_{2} \mathrm{CHCH}_{2} \mathrm{OCS}_{2} \mathrm{Na}+\mathrm{H}_{2} \mathrm{O} \Leftrightarrow \mathrm{CS}_{2}+\left(\mathrm{CH}_{3}\right)_{2} \mathrm{CHCH}_{2} \mathrm{OH}+\mathrm{NaOH}
$$

2. When $\mathrm{pH}$ decreased, the decomposition of SIBX can be rewritten as:

$$
\left(\mathrm{CH}_{3}\right) \mathrm{CHCH}_{2} \mathrm{OCS}_{2} \mathrm{Na}+\mathrm{H}^{+} \rightarrow\left(\mathrm{CH}_{3}\right) \mathrm{CHCH}_{2} \mathrm{OH}+\mathrm{CS}_{2} \uparrow+\mathrm{Na}^{+}
$$




$$
\left(\mathrm{CH}_{3}\right) \mathrm{CHCH}_{2} \mathrm{OCS}_{2}^{-}+\mathrm{H}^{+} \rightarrow\left(\mathrm{CH}_{3}\right) \mathrm{CHCH}_{2} \mathrm{OCS}_{2}^{-} \mathrm{H}^{+}
$$

According to this reaction, SIBX would be stabilized and $\mathrm{CS}_{2}$ generation would

318

$$
3 \mathrm{CS}_{2}+6 \mathrm{OH}^{-} \rightarrow 2 \mathrm{CS}_{3}^{2-}+\mathrm{CO}_{3}^{2-}+3 \mathrm{H}_{2} \mathrm{O}
$$
interacting with $\mathrm{OH}^{-}$via (Report, 2000): expressed as:

3. When $\mathrm{pH}$ increased (i.e. $\mathrm{OH}^{-}$increased), the $\mathrm{OH}^{-}$ions could inhibit Eq. 1 from occurring, so the generation of $\mathrm{CS}_{2}$ would be reduced. Furthermore, the $\mathrm{CS}_{2}$ generated would start

Combining Eq. 8 with Eq. 1, SIBX decomposition in weakly alkaline solution can be

$$
6\left(\mathrm{CH}_{3}\right) \mathrm{CHCH}_{2} \mathrm{OCS}_{2} \mathrm{Na}+3 \mathrm{H}_{2} \mathrm{O} \rightarrow 6 \mathrm{Na}^{+}+6\left(\mathrm{CH}_{3}\right) \mathrm{CHCH}_{2} \mathrm{OH}+\mathrm{CO}_{3}^{2-}+3 \mathrm{CS}_{2}+2 \mathrm{CS}_{3}^{2-}
$$

$$
\mathrm{CS}_{2}+6 \mathrm{OH}^{-} \rightarrow 2 \mathrm{~S}^{2-}+\mathrm{CO}_{3}^{2-}+3 \mathrm{H}_{2}
$$



expressed as:

$$
\left(\mathrm{CH}_{3}\right) \mathrm{CHCH}_{2} \mathrm{OCS}_{2} \mathrm{Na}+5 \mathrm{OH}^{-} \rightarrow \mathrm{Na}^{+}+\left(\mathrm{CH}_{3}\right) \mathrm{CHCH}_{2} \mathrm{OH}+\mathrm{CO}_{3}^{2-}+2 \mathrm{~S}^{2-}+2 \mathrm{H}_{2} \mathrm{O}
$$

337 generated when Eq. 10 dominates. the decomposition behavior under different $\mathrm{pH}$ conditions. They clarify the discrepancies in

340 literature (e.g., whether there was a maximum and whether decomposition still decreased in 341 alkaline solution). Figure 7 shows a schematic of the likely types of compounds at different $\mathrm{pH}$ 342 levels based on the above reactions. Compounds such as dixanthogen (Pomianowski and Leja, 343 1963), perxanthate (Pomianowski and Leja, 1963; Sun and Forsling, 1997), and monothio- and 344 dithio- carbonates (Philip and Fichte, 1960) that appear under alkaline conditions are also 345 included. 


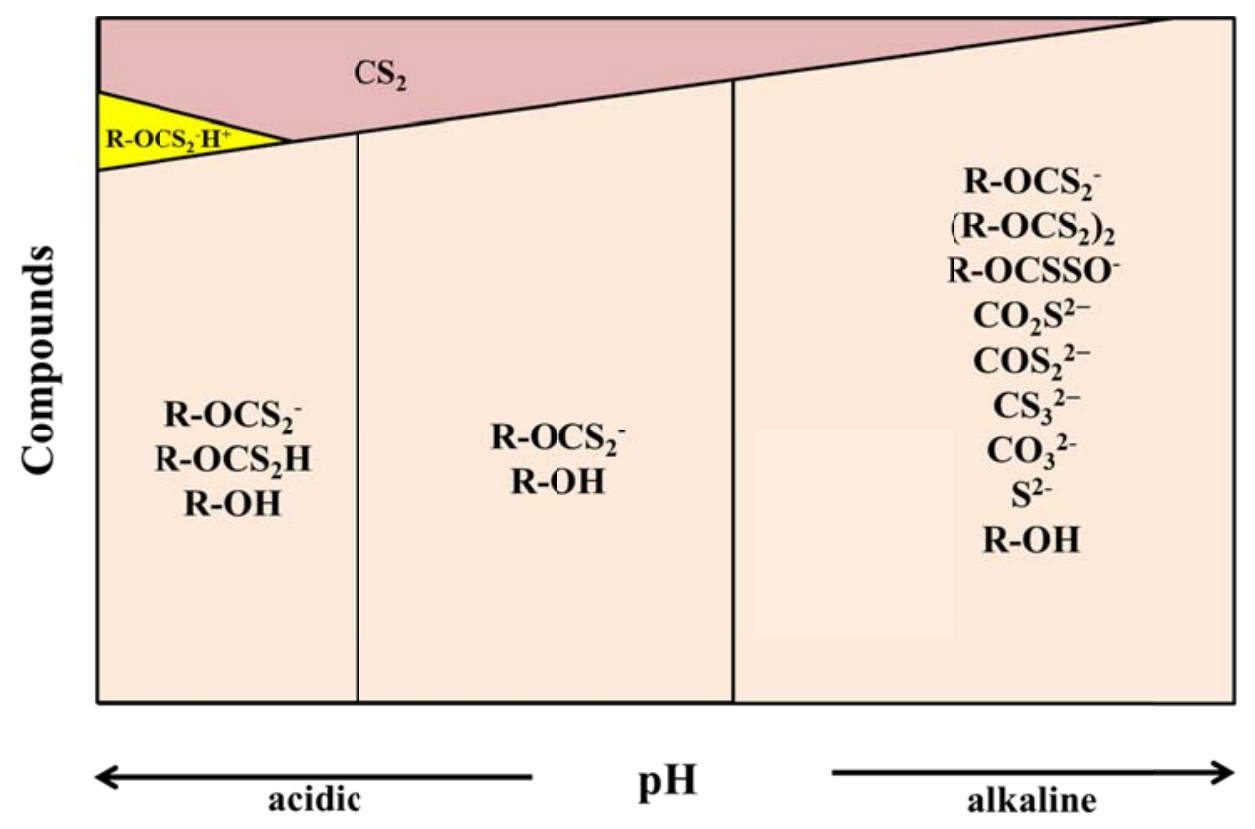

Figure 7. Distribution of xanthate compounds in different $\mathrm{pH}$ regions;

$\mathrm{CS}_{2}$ : carbon disulfide; $\mathrm{R}-\mathrm{OCS}_{2}^{-}$: xanthate ion; $\mathrm{R}-\mathrm{OCS}_{2} \mathrm{H}$ : xanthic acid; $\mathrm{R}_{-} \mathrm{OCS}_{2}{ }^{-} \mathrm{H}^{+}$: xanthic acid-like compound; $\mathrm{R}-\mathrm{OH}$ : alcohol; $(\mathrm{R}-\mathrm{OCS})_{2}$ : dixanthogen; $\mathrm{R}-\mathrm{OCS}_{2} \mathrm{O}^{-}$: perxanthate; $\mathrm{CO}_{2} \mathrm{~S}^{2-}$ : monothiocarbonate; $\mathrm{COS}_{2}{ }^{2-}$ : dithiocarbonate; $\mathrm{CS}_{3}{ }^{2-}$ : trithiocarbonate; $\mathrm{S}^{2-}$ : sulfide

\section{Conclusions}

Compared to the SFT method based on UV-vis spectroscopy, our GC-MS based method provided a direct approach for studying xanthate decomposition behavior and clarified previous discrepancies. The decomposition kinetics was re-evaluated by calculations based on the $\mathrm{CS}_{2}$ measured in the gas phase. The impact of crucial factors such as $\mathrm{pH}$ could be investigated indepth using this method. A systematic analysis over a wide range of $\mathrm{pH}$ was rationalized in terms of multiple reactions that occur in parallel and sequentially along with the decomposition reaction. Features such as the decomposition maximum at low $\mathrm{pH}$ were confirmed and a plausible explanation offered. This study may be used as the basis for devising possible measures 
362 that could be taken to mitigate decomposition (e.g., by modifying operation parameters to reduce

363 xanthate decomposition without affecting its performance). It is also a control for further studies

364 of decomposition under flotation conditions.

\section{Acknowledgements}

367 This work was supported by CPaSS (Center for Particulate and Surfactant Systems), a joint NSF 368 IUCRC (Industry/University Cooperative Research Center) that includes the University of 369 Florida and Columbia University. Special thanks are given to the GMPP (Greener Mineral 370 Processing Program) members in this center, namely Barrick Gold Corporation, Cytec Industries, 371 Inc., Freeport McMoRan Copper \& Gold, Inc., Newmont Mining Corporation, and Vale. We are 372 also grateful for all the suggestions and comments from other industrial sponsors and research 373 group members.

375 References

Ballard, D.G.H., Bamford, C.H., Gary, K.L., Totman, E.D., 1954. Private

377 Communication. Courtauds Limited, Maidenhead, England; Viscose Research Lab, Coventry. Finkelstein, N.P., 1967. kinetic and thermodynamic aspects of the interaction between 379 potassium ethyl xanthate and oxygen in aqueous solution. Trans. Instn. Min. Metall. 76. 
Healy, T.W., 1984. Pulp chemistry, surface chemistry and flotation, in: Jones, M.H., 383 Woodcock, J.T. (Eds.), Principles of Mineral Flotation. Australia Institute of Mining and 384 Metallurgy, Parkville, Victoria, Australia, pp. 43-56.

385

386

Iwasaki, I., Cooke, S.R.B., 1958. The decomposition of xanthate in acid solution. J Am Chem Soc 80, 285-288.

Iwasaki, I., Cooke, S.R.B., 1959. Dissociation constant of xanthic acid as determined by spectrophotometric method. J Phys Chem-Us 63.

Iwasaki, I., Cooke, S.R.B., 1964. Decomposition mechanism of xanthate in acid solution as determined by spectrophotometric method. J Phys Chem-Us 68, 2031-\&.

Klein, E., Bosarge, J.K., Norman, I., 1960. Spectrophotometric determination of fast xanthate decomposition kinetics. J Phys Chem-Us 64, 1666-1670.

Majima, H., 1961. Fundamental studies on the collection of sulfide minerals with xanthic acids: I. on the dissociation and decomposition of xanthic acids. Science Reports of the Research Institute, Tohoku University A.13.

OSHA, Occupational Safety \& Health Administration Annotated OSHA Z-2 Table.

Philip, B., Fichte, C., 1960. Kinetic studies on the decomposition of xanthate. Faserforsch, Textiltech 11.

Poling, G.W., 1976. Reactions between thiol reagents and sulfide minerals, in: Fuerstenau, M.C. (Ed.), Flotation (A. M. Gaudin Memorial Volume). American Institute of Mining and Petroleum Engineers, New York, pp. 334-363.

Pomianowski, A., Leja, J., 1963. Spectrophotometric study of xanthate and dixanthogen solutions. Can J Chem 41, 2219-\&.

Rao, S.R., 1971. Xanthates and Related Compounds. Marcel Dekker, Inc., New York. 
406

407

408

409

410

411

412

413

414

415

416

417

(National Industrial Chemicals Notification and Assessment Scheme), Austrilia.

Salamy, S.G., Nixon, J.C., 1953. The application of electrochemical methods to flotation research, Recent Developments in Mineral Dressing, 518 ed. Institution of Mining and Metallurgy, London, pp. 503-518.

Spottiswod, D.J., Kelly, E.G., 1982. Mineral Processing: An Introduction to the Principles. John Wiley \& Sons Inc.

Sun, Z., Forsling, W., 1997. The degradation kinectis of ethyl xanthate as a function of $\mathrm{pH}$ in aqueous solution. Mineral Engineering 10.

Tipman, R.N., Leja, J., 1975. Reactivity of xanthate and dixanthogen in aqueous solutions at different pH. Colloid Polym Sci 253.

Tornell, B., 1966a. Xanthate Decomposition in Acid Media .1. Experimental Technique and a Study of Decomposition of Ethyl Xanthate. Sven Papperstidn 69, 658-\&.

Tornell, B., 1966b. Xanthate Decomposition in Acid Media .2. Decomposition of a Dixanthate and a Study of Influence of Molecular Aggregation. Sven Papperstidn 69, 695-\&.

Tornell, B., 1967. Xanthate Decomposition in Acid Media .3. Cellulose Xanthate Experimental Details and Empirical Results. Sven Papperstidn 70, 268-\&.

Wills, B.A., 2006. Wills' Mineral Processing Technology, Seventh edition ed. Butterworth-Heinemann.

Woods, R., 1976. Electrochemistry of sulfide flotation, in: Fuerstenau, M.C. (Ed.), Flotation (A. M. Gaudin Memorial Volume). American Institute of Mining and Petroleum Engineers, New York, pp. 298-333. 
428 (Eds.), Principles of Mineral Flotation. Australia Institute of Mining and Metallurgy, Parkville, 429 Victoria, Australia, pp. 91-115.

430 Woods, R., 1996. Chemisorption of Thiols on Metals and Metal Sulfides, in: Bockris, 431 J.O., Conway, B.E., White, R.E. (Eds.), Modern Aspects of Electrochemistry. Plenum Press, 432 New York, pp. 401-453.

433

434

435

436

437

438

439

440

441

442

443

444 


\section{Supplement Information}

446 1. Standard Calibration Equation for $\mathrm{CS}_{2}$ (Carbon Disulfide)

\begin{tabular}{|c|c|c|}
\hline \multirow{2}{*}{ Magnitude of Peak Area } & \multicolumn{2}{|c|}{ Calibration Equation: } \\
\cline { 2 - 3 } & Slope $\left(\mathrm{x} 10^{11}\right)$ & Intercept \\
\hline $10^{5}$ & 2.38 & $2.6 \mathrm{E}-06$ \\
\hline $10^{6}$ & 2.50 & $1.6 \mathrm{E}-05$ \\
\hline $10^{7}$ & 3.15 & $-1.34 \mathrm{E}-04$ \\
\hline $10^{8}$ & 4.26 & $-2.58 \mathrm{E}-03$ \\
\hline
\end{tabular}

*In our tests the headspace in the vial is $9 \mathrm{ml}$.

2. $\mathrm{CS}_{2}$ Generated from $0.05 w t . \%$ SIBX Solution at 25,50 and $70^{\circ} \mathrm{C}$ up to 4 hours (for Figure 4)

\begin{tabular}{|c|c|c|c|c|}
\hline \multirow{2}{*}{ Time (h) } & \multicolumn{4}{|c|}{$25^{\circ} \mathrm{C}$} \\
\hline & Peak Area & Mass (mg) & Average Mass (mg) & Error \\
\hline \multirow{3}{*}{0.5} & $1.32 \mathrm{E}+05$ & $5.16 \mathrm{E}-05$ & \multirow{3}{*}{$5.14 \mathrm{E}-05$} & \multirow{3}{*}{$9.92 \mathrm{E}-08$} \\
\hline & $1.30 \mathrm{E}+05$ & $5.12 \mathrm{E}-05$ & & \\
\hline & $1.31 \mathrm{E}+05$ & $5.14 \mathrm{E}-05$ & & \\
\hline \multirow{3}{*}{1} & $4.89 \mathrm{E}+05$ & $1.28 \mathrm{E}-04$ & \multirow{3}{*}{$1.26 \mathrm{E}-04$} & \multirow{3}{*}{$8.58 \mathrm{E}-07$} \\
\hline & $4.75 \mathrm{E}+05$ & $1.25 \mathrm{E}-04$ & & \\
\hline & $4.80 \mathrm{E}+05$ & $1.26 \mathrm{E}-04$ & & \\
\hline \multirow{3}{*}{2} & $1.32 \mathrm{E}+06$ & $4.40 \mathrm{E}-04$ & \multirow{3}{*}{$4.40 \mathrm{E}-04$} & \multirow{3}{*}{$3.97 \mathrm{E}-07$} \\
\hline & $1.32 \mathrm{E}+06$ & $4.41 \mathrm{E}-04$ & & \\
\hline & $1.31 \mathrm{E}+06$ & $4.39 \mathrm{E}-04$ & & \\
\hline \multirow{3}{*}{3} & $1.97 \mathrm{E}+06$ & $5.86 \mathrm{E}-04$ & \multirow{3}{*}{$5.88 \mathrm{E}-04$} & \multirow{3}{*}{$5.01 \mathrm{E}-06$} \\
\hline & $2.02 \mathrm{E}+06$ & $5.98 \mathrm{E}-04$ & & \\
\hline & $1.94 \mathrm{E}+06$ & $5.81 \mathrm{E}-04$ & & \\
\hline \multirow{2}{*}{4} & $2.76 \mathrm{E}+06$ & $7.64 \mathrm{E}-04$ & \multirow{2}{*}{$7.63 \mathrm{E}-04$} & \multirow{2}{*}{$2.91 \mathrm{E}-0 \mathrm{C}$} \\
\hline & $2.77 \mathrm{E}+06$ & $7.68 \mathrm{E}-04$ & & \\
\hline
\end{tabular}




\begin{tabular}{|c|c|c|c|c|}
\hline & $2.73 \mathrm{E}+06$ & $7.58 \mathrm{E}-04$ & & \\
\hline \multirow{2}{*}{ Time (h) } & \multicolumn{4}{|c|}{$50^{\circ} \mathrm{C}$} \\
\hline & Peak Area & Mass (mg) & Average Mass (mg) & Error \\
\hline \multirow{3}{*}{0.5} & $6.35 \mathrm{E}+06$ & $1.57 \mathrm{E}-03$ & \multirow{3}{*}{$1.57 \mathrm{E}-03$} & \multirow{3}{*}{ 7.79E-06 } \\
\hline & $6.29 \mathrm{E}+06$ & $1.56 \mathrm{E}-03$ & & \\
\hline & $6.41 \mathrm{E}+06$ & $1.59 \mathrm{E}-03$ & & \\
\hline \multirow{3}{*}{1} & $1.45 \mathrm{E}+07$ & $2.89 \mathrm{E}-03$ & \multirow{3}{*}{$2.90 \mathrm{E}-03$} & \multirow{3}{*}{$2.61 \mathrm{E}-05$} \\
\hline & $1.44 \mathrm{E}+07$ & $2.87 \mathrm{E}-03$ & & \\
\hline & $1.47 \mathrm{E}+07$ & $2.95 \mathrm{E}-03$ & & \\
\hline \multirow{3}{*}{2} & $2.78 \mathrm{E}+07$ & $6.69 \mathrm{E}-03$ & \multirow{3}{*}{$6.53 \mathrm{E}-03$} & \multirow{3}{*}{$8.09 \mathrm{E}-05$} \\
\hline & $2.69 \mathrm{E}+07$ & $6.42 \mathrm{E}-03$ & & \\
\hline & $2.71 \mathrm{E}+07$ & $6.49 \mathrm{E}-03$ & & \\
\hline \multirow{3}{*}{3} & $4.17 \mathrm{E}+07$ & $1.06 \mathrm{E}-02$ & \multirow{3}{*}{$1.07 \mathrm{E}-02$} & \multirow{3}{*}{$3.29 \mathrm{E}-05$} \\
\hline & $4.20 \mathrm{E}+07$ & $1.07 \mathrm{E}-02$ & & \\
\hline & $4.17 \mathrm{E}+07$ & $1.06 \mathrm{E}-02$ & & \\
\hline \multirow{3}{*}{4} & $5.40 \mathrm{E}+07$ & $1.41 \mathrm{E}-02$ & \multirow{3}{*}{$1.42 \mathrm{E}-02$} & \multirow{3}{*}{$1.02 \mathrm{E}-04$} \\
\hline & $5.50 \mathrm{E}+07$ & $1.44 \mathrm{E}-02$ & & \\
\hline & $5.39 \mathrm{E}+07$ & $1.41 \mathrm{E}-02$ & & \\
\hline \multirow{2}{*}{ Time (h) } & \multicolumn{4}{|c|}{$70^{\circ} \mathrm{C}$} \\
\hline & Peak Area & Mass (mg) & Average Mass (mg) & Error \\
\hline \multirow{3}{*}{0.5} & $5.28 \mathrm{E}+07$ & $1.38 \mathrm{E}-02$ & \multirow{3}{*}{$1.37 \mathrm{E}-02$} & \multirow{3}{*}{$3.53 \mathrm{E}-04$} \\
\hline & $5.47 \mathrm{E}+07$ & $1.43 \mathrm{E}-02$ & & \\
\hline & $5.04 \mathrm{E}+07$ & $1.31 \mathrm{E}-02$ & & \\
\hline \multirow{3}{*}{1} & $9.83 \mathrm{E}+07$ & $2.67 \mathrm{E}-02$ & \multirow{3}{*}{ 2.67E-02 } & \multirow{3}{*}{$2.44 \mathrm{E}-04$} \\
\hline & $9.69 \mathrm{E}+07$ & $2.63 \mathrm{E}-02$ & & \\
\hline & $9.99 \mathrm{E}+07$ & $2.71 \mathrm{E}-02$ & & \\
\hline \multirow{3}{*}{2} & $1.90 \mathrm{E}+08$ & $4.98 \mathrm{E}-02$ & \multirow{3}{*}{ 4.71E-02 } & \multirow{3}{*}{$2.36 \mathrm{E}-03$} \\
\hline & $1.71 \mathrm{E}+08$ & 4.24E-02 & & \\
\hline & $1.89 \mathrm{E}+08$ & 4.92E-02 & & \\
\hline \multirow{3}{*}{3} & $2.41 \mathrm{E}+08$ & $6.95 \mathrm{E}-02$ & & \\
\hline & $2.45 \mathrm{E}+08$ & $7.07 \mathrm{E}-02$ & $7.06 \mathrm{E}-02$ & $5.70 \mathrm{E}-04$ \\
\hline & $2.47 \mathrm{E}+08$ & $7.15 \mathrm{E}-02$ & & \\
\hline & $3.07 \mathrm{E}+08$ & $9.46 \mathrm{E}-02$ & & \\
\hline 4 & $2.92 \mathrm{E}+08$ & $8.89 \mathrm{E}-02$ & 8.99E-02 & $2.43 \mathrm{E}-03$ \\
\hline & $2.85 \mathrm{E}+08$ & $8.64 \mathrm{E}-02$ & & \\
\hline
\end{tabular}




\begin{tabular}{|c|c|c|c|c|c|c|c|}
\hline \multicolumn{8}{|c|}{$25^{\circ} \mathrm{C}$} \\
\hline $\begin{array}{l}\text { Time } \\
\text { (h) }\end{array}$ & $\begin{array}{c}\mathrm{CS}_{2} \text { Mass } \\
(\mathrm{mg})\end{array}$ & $\begin{array}{c}\Delta \mathrm{m}(\mathrm{SIBX} \\
)(\mathrm{mg})\end{array}$ & $\begin{array}{c}\mathrm{m}_{\mathrm{t}}(\mathrm{SIBX}) \\
(\mathrm{mg})\end{array}$ & $\begin{array}{l}{[\mathrm{SIBX}]_{\mathrm{t}}} \\
(\mathrm{mol} / \mathrm{L})\end{array}$ & $\ln [\mathrm{SIBX}]_{\mathrm{t}}$ & $\ln [\mathrm{SIBX}]_{0}$ & $\begin{array}{c}\ln [\mathrm{SIBX}]_{0^{-}} \\
\ln [\mathrm{SIBX}]_{\mathrm{t}}\end{array}$ \\
\hline \multirow{3}{*}{0.5} & $5.16 \mathrm{E}-05$ & $1.17 \mathrm{E}-04$ & $5.00 \mathrm{E}-01$ & $2.91 \mathrm{E}+00$ & -5.84087505 & \multirow{3}{*}{-5.84064166} & 0.000233393 \\
\hline & $5.12 \mathrm{E}-05$ & $1.16 \mathrm{E}-04$ & $5.00 \mathrm{E}-01$ & $2.91 \mathrm{E}+00$ & -5.87087350 & & 0.000231842 \\
\hline & $5.14 \mathrm{E}-05$ & $1.16 \mathrm{E}-04$ & $5.00 \mathrm{E}-01$ & $2.91 \mathrm{E}+00$ & -5.84087437 & & 0.000232714 \\
\hline \multirow{3}{*}{1} & $1.28 \mathrm{E}-04$ & $2.90 \mathrm{E}-04$ & $5.00 \mathrm{E}-01$ & $2.91 \mathrm{E}+00$ & -5.84122158 & \multirow{3}{*}{-5.84064166} & 0.000579925 \\
\hline & $1.25 \mathrm{E}-04$ & $2.83 \mathrm{E}-04$ & $5.00 \mathrm{E}-01$ & $2.91 \mathrm{E}+00$ & -5.84120829 & & 0.00056664 \\
\hline & $1.26 \mathrm{E}-04$ & $2.86 \mathrm{E}-04$ & $5.00 \mathrm{E}-01$ & $2.91 \mathrm{E}+00$ & -5.84121305 & & 0.000571391 \\
\hline \multirow{3}{*}{2} & $4.40 \mathrm{E}-04$ & $9.95 \mathrm{E}-04$ & 4.99E-01 & $2.90 \mathrm{E}+00$ & -5.84263434 & \multirow{3}{*}{-5.84064166} & 0.001992687 \\
\hline & $4.41 \mathrm{E}-04$ & $9.97 \mathrm{E}-04$ & 4.99E-01 & $2.90 \mathrm{E}+00$ & -5.84263843 & & 0.001996767 \\
\hline & $4.39 \mathrm{E}-04$ & $9.94 \mathrm{E}-04$ & 4.99E-01 & $2.90 \mathrm{E}+00$ & -5.84263230 & & 0.001990646 \\
\hline \multirow{3}{*}{3} & $5.86 \mathrm{E}-04$ & $1.33 \mathrm{E}-03$ & 4.99E-01 & $2.90 \mathrm{E}+00$ & -5.84329770 & \multirow{3}{*}{-5.84064166} & 0.002656047 \\
\hline & 5.98E-04 & $1.35 \mathrm{E}-03$ & 4.99E-01 & $2.90 \mathrm{E}+00$ & -5.84335181 & & 0.002710156 \\
\hline & $5.81 \mathrm{E}-04$ & $1.32 \mathrm{E}-03$ & 4.99E-01 & $2.90 \mathrm{E}+00$ & -5.81327525 & & 0.002633587 \\
\hline \multirow{3}{*}{4} & 7.64E-04 & $1.73 \mathrm{E}-03$ & 4.98E-01 & $2.90 \mathrm{E}+00$ & -5.84410658 & \multirow{3}{*}{-5.84064166} & 0.003464921 \\
\hline & $7.68 \mathrm{E}-04$ & $1.74 \mathrm{E}-03$ & $4.98 \mathrm{E}-01$ & $2.90 \mathrm{E}+00$ & -5.84412190 & & 0.003480247 \\
\hline & $7.58 \mathrm{E}-04$ & $1.71 \mathrm{E}-03$ & $4.98 \mathrm{E}-01$ & $2.90 \mathrm{E}+00$ & -5.84407695 & & 0.003435291 \\
\hline \multicolumn{8}{|c|}{$50^{\circ} \mathrm{C}$} \\
\hline $\begin{array}{l}\text { Time } \\
\text { (h) }\end{array}$ & $\begin{array}{c}\mathrm{CS}_{2} \text { Mass } \\
(\mathrm{mg})\end{array}$ & $\begin{array}{c}\Delta \mathrm{m}(\mathrm{SIBX} \\
)(\mathrm{mg})\end{array}$ & $\begin{array}{c}\mathrm{m}_{\mathrm{t}}(\mathrm{SIBX}) \\
(\mathrm{mg})\end{array}$ & $\begin{array}{l}{[\mathrm{SIBX}]_{\mathrm{t}}} \\
(\mathrm{mol} / \mathrm{L})\end{array}$ & $\ln [\mathrm{SIBX}]_{\mathrm{t}}$ & $\ln [\mathrm{SIBX}]_{0}$ & $\begin{array}{c}\ln [\mathrm{SIBX}]_{0^{-}} \\
\ln [\mathrm{SIBX}]_{\mathrm{t}}\end{array}$ \\
\hline \multirow{3}{*}{0.5} & $1.57 \mathrm{E}-03$ & $3.56 \mathrm{E}-03$ & $4.96 \mathrm{E}-01$ & $2.89 \mathrm{E}+00$ & -5.84778437 & \multirow{3}{*}{-5.84064166} & 0.007142711 \\
\hline & $1.56 \mathrm{E}-03$ & $3.53 \mathrm{E}-03$ & $4.96 \mathrm{E}-01$ & $2.89 \mathrm{E}+00$ & -5.84772284 & & 0.007081184 \\
\hline & $1.59 \mathrm{E}-03$ & $3.59 \mathrm{E}-03$ & $4.96 \mathrm{E}-01$ & $2.89 \mathrm{E}+00$ & -5.8478459 & & 0.007204242 \\
\hline \multirow{3}{*}{1} & $2.89 \mathrm{E}-03$ & $6.55 \mathrm{E}-03$ & $4.93 \mathrm{E}-01$ & $2.87 \mathrm{E}+00$ & -5.85382025 & \multirow{3}{*}{-5.84064166} & 0.013178589 \\
\hline & $2.87 \mathrm{E}-03$ & $6.49 \mathrm{E}-03$ & $4.94 \mathrm{E}-01$ & $2.87 \mathrm{E}+00$ & -5.85370318 & & 0.013061522 \\
\hline & $2.95 \mathrm{E}-03$ & $6.69 \mathrm{E}-03$ & $4.93 \mathrm{E}-01$ & $2.87 \mathrm{E}+00$ & -5.8541065 & & 0.013464812 \\
\hline \multirow{3}{*}{2} & $6.69 \mathrm{E}-03$ & $1.51 \mathrm{E}-02$ & $4.85 \mathrm{E}-01$ & $2.82 \mathrm{E}+00$ & -5.8713918 & \multirow{3}{*}{-5.84064166} & 0.02949325 \\
\hline & $6.42 \mathrm{E}-03$ & $1.45 \mathrm{E}-02$ & $4.85 \mathrm{E}-01$ & $2.82 \mathrm{E}+00$ & -5.87013491 & & 0.030750152 \\
\hline & $6.49 \mathrm{E}-03$ & $1.47 \mathrm{E}-02$ & $4.85 \mathrm{E}-01$ & $2.82 \mathrm{E}+00$ & -5.87045229 & & 0.029810634 \\
\hline \multirow{3}{*}{3} & $1.06 \mathrm{E}-02$ & $2.41 \mathrm{E}-02$ & $4.76 \mathrm{E}-01$ & $2.77 \mathrm{E}+00$ & -5.88993829 & \multirow{3}{*}{-5.84064166} & 0.049296636 \\
\hline & $1.07 \mathrm{E}-02$ & $2.43 \mathrm{E}-02$ & $4.76 \mathrm{E}-01$ & $2.77 \mathrm{E}+00$ & -5.89036996 & & 0.049728304 \\
\hline & $1.06 \mathrm{E}-02$ & $2.40 \mathrm{E}-02$ & $4.76 \mathrm{E}-01$ & $2.77 \mathrm{E}+00$ & -5.88987086 & & 0.049229205 \\
\hline \multirow{3}{*}{4} & $1.41 \mathrm{E}-02$ & $3.20 \mathrm{E}-02$ & $4.68 \mathrm{E}-01$ & $2.72 \mathrm{E}+00$ & -5.9066798 & \multirow{3}{*}{-5.84064166} & 0.066038122 \\
\hline & $1.44 \mathrm{E}-02$ & $3.26 \mathrm{E}-02$ & $4.67 \mathrm{E}-01$ & $2.72 \mathrm{E}+00$ & -5.9080522 & & 0.067410502 \\
\hline & $1.41 \mathrm{E}-02$ & $3.19 \mathrm{E}-02$ & $4.68 \mathrm{E}-01$ & $2.72 \mathrm{E}+00$ & -5.90648780 & & 0.065846139 \\
\hline
\end{tabular}


$70^{\circ} \mathrm{C}$

\begin{tabular}{|c|c|c|c|c|c|c|c|}
\hline $\begin{array}{l}\text { Time } \\
\text { (h) }\end{array}$ & $\begin{array}{c}\mathrm{CS}_{2} \text { Mass } \\
(\mathrm{mg})\end{array}$ & $\begin{array}{c}\Delta \mathrm{m}(\mathrm{SIBX} \\
)(\mathrm{mg})\end{array}$ & $\begin{array}{c}\mathrm{m}_{\mathrm{t}}(\mathrm{SIBX}) \\
(\mathrm{mg})\end{array}$ & $\begin{array}{l}{[\mathrm{SIBX}]_{\mathrm{t}}} \\
(\mathrm{mol} / \mathrm{L})\end{array}$ & $\ln [\mathrm{SIBX}]_{\mathrm{t}}$ & $\ln [\mathrm{SIBX}]_{0}$ & $\begin{array}{l}\ln [\mathrm{SIBX}]_{0^{-}} \\
\ln [\mathrm{SIBX}]_{\mathrm{t}}\end{array}$ \\
\hline \multirow{3}{*}{0.5} & $1.38 \mathrm{E}-02$ & $3.11 \mathrm{E}-02$ & 4.69E-01 & $2.73 \mathrm{E}-03$ & -5.90496675 & \multirow{3}{*}{-5.84064166} & 0.064325088 \\
\hline & $1.43 \mathrm{E}-02$ & $3.24 \mathrm{E}-02$ & $4.68 \mathrm{E}-01$ & $2.72 \mathrm{E}-03$ & -5.90766101 & & 0.067019351 \\
\hline & $1.31 \mathrm{E}-02$ & $2.96 \mathrm{E}-02$ & 4.70E-01 & $2.73 \mathrm{E}-03$ & -5.90177011 & & 0.061128456 \\
\hline \multirow{3}{*}{1} & $2.67 \mathrm{E}-02$ & $6.04 \mathrm{E}-02$ & $4.40 \mathrm{E}-01$ & $2.56 \mathrm{E}-03$ & -5.96929177 & \multirow{3}{*}{-5.84064166} & 0.128650115 \\
\hline & $2.63 \mathrm{E}-02$ & $5.95 \mathrm{E}-02$ & 4.41E-01 & $2.56 \mathrm{E}-03$ & -5.96723544 & & 0.126593781 \\
\hline & $2.71 \mathrm{E}-02$ & $6.14 \mathrm{E}-02$ & 4.39E-01 & $2.55 \mathrm{E}-03$ & -5.97158357 & & 0.130941916 \\
\hline \multirow{3}{*}{2} & 4.98E-02 & $1.13 \mathrm{E}-01$ & $3.87 \mathrm{E}-01$ & $2.25 \mathrm{E}-03$ & -6.09583473 & \multirow{3}{*}{-5.84064166} & 0.255193075 \\
\hline & $4.24 \mathrm{E}-02$ & $9.60 \mathrm{E}-02$ & $4.04 \mathrm{E}-01$ & $2.35 \mathrm{E}-03$ & -6.05394027 & & 0.21329861 \\
\hline & $4.92 \mathrm{E}-02$ & $1.11 \mathrm{E}-01$ & $3.89 \mathrm{E}-01$ & $2.26 \mathrm{E}-03$ & -6.09264333 & & 0.252001672 \\
\hline \multirow{3}{*}{3} & $6.95 \mathrm{E}-02$ & $1.57 \mathrm{E}-01$ & $3.43 \mathrm{E}-01$ & $1.99 \mathrm{E}-03$ & -6.21864512 & \multirow{3}{*}{-5.84064166} & 0.378003458 \\
\hline & $7.07 \mathrm{E}-02$ & $1.60 \mathrm{E}-01$ & $3.40 \mathrm{E}-01$ & $1.98 \mathrm{E}-03$ & -6.22659187 & & 0.385950213 \\
\hline & $7.15 \mathrm{E}-02$ & $1.62 \mathrm{E}-01$ & $3.38 \mathrm{E}-01$ & $1.97 \mathrm{E}-03$ & -6.23166346 & & 0.391021806 \\
\hline \multirow{3}{*}{4} & $9.46 \mathrm{E}-02$ & $2.14 \mathrm{E}-01$ & $2.86 \mathrm{E}-01$ & $1.66 \mathrm{E}-03$ & -6.39951214 & \multirow{3}{*}{-5.84064166} & 0.558870481 \\
\hline & 8.89E-02 & $2.01 \mathrm{E}-01$ & $2.99 \mathrm{E}-01$ & $1.74 \mathrm{E}-03$ & -6.35524546 & & 0.514603807 \\
\hline & 8.64E-02 & $1.95 \mathrm{E}-01$ & $3.05 \mathrm{E}-01$ & $1.77 \mathrm{E}-03$ & -6.33644748 & & 0.495805821 \\
\hline
\end{tabular}

451

452 By plotting $\ln [\mathrm{SIBX}]_{0}-\ln [\mathrm{SIBX}]_{\mathrm{t}}$ against time, the slope is the rate constant.

\begin{tabular}{|c|c|c|c|}
\hline Temperature $\left({ }^{\circ} \mathrm{C}\right)$ & Linear Fit $-\mathrm{R}^{2}$ & Rate Constant or Slope & Standard Error \\
\hline 25 & 0.98 & $9.3 \mathrm{E}-04$ & $3.4 \mathrm{E}-05$ \\
\hline 50 & 0.99 & $1.7 \mathrm{E}-02$ & $2.7 \mathrm{E}-04$ \\
\hline 70 & 0.99 & $1.3 \mathrm{E}-01$ & $3.3 \mathrm{E}-03$ \\
\hline
\end{tabular}

453

4. $\mathrm{CS}_{2}$ Generated vs. Initial SIBX for 0.05 to $1 \mathrm{wt} . \%$ solution at $50^{\circ} \mathrm{C}$ for $2 \mathrm{~h}$ (for Figure 5)

\begin{tabular}{|c|c|c|c|c|}
\hline Concentration & Peak Area & Mass (mg) & Average Mass (mg) & Error \\
\hline \multirow{3}{*}{0.05} & $2.65 \mathrm{E}+07$ & $6.32 \mathrm{E}-03$ & \multirow{3}{*}{$6.49 \mathrm{E}-03$} & \multirow{3}{*}{$9.79 \mathrm{E}-05$} \\
\hline & $2.71 \mathrm{E}+07$ & $6.49 \mathrm{E}-03$ & & \\
\hline & $2.77 \mathrm{E}+07$ & $6.66 \mathrm{E}-03$ & & \\
\hline \multirow{3}{*}{0.1} & $5.01 \mathrm{E}+07$ & $1.30 \mathrm{E}-02$ & \multirow{3}{*}{$1.34 \mathrm{E}-02$} & \multirow{3}{*}{$2.23 \mathrm{E}-04$} \\
\hline & $5.28 \mathrm{E}+07$ & $1.38 \mathrm{E}-02$ & & \\
\hline & $5.12 \mathrm{E}+07$ & $1.33 \mathrm{E}-02$ & & \\
\hline 0.25 & $1.55 \mathrm{E}+08$ & $3.63 \mathrm{E}-02$ & $3.33 \mathrm{E}-02$ & $1.69 \mathrm{E}-03$ \\
\hline
\end{tabular}




\begin{tabular}{|c|c|c|c|c|}
\hline & $1.40 \mathrm{E}+08$ & $3.05 \mathrm{E}-02$ & & \\
\hline & $1.47 \mathrm{E}+08$ & $3.32 \mathrm{E}-02$ & & \\
\hline \multirow{3}{*}{0.5} & $2.44 \mathrm{E}+08$ & 7.04E-02 & \multirow{3}{*}{ 6.69E-02 } & \multirow{3}{*}{$2.15 \mathrm{E}-03$} \\
\hline & $2.35 \mathrm{E}+08$ & $6.72 \mathrm{E}-02$ & & \\
\hline & $2.24 \mathrm{E}+08$ & $6.30 \mathrm{E}-02$ & & \\
\hline \multirow{3}{*}{0.75} & $3.19 \mathrm{E}+08$ & 9.94E-02 & \multirow{3}{*}{$1.01 \mathrm{E}-01$} & \multirow{3}{*}{$4.16 \mathrm{E}-03$} \\
\hline & $3.09 \mathrm{E}+08$ & $9.54 \mathrm{E}-02$ & & \\
\hline & $3.45 \mathrm{E}+08$ & $1.09 \mathrm{E}-01$ & & \\
\hline \multirow{3}{*}{1} & $4.31 \mathrm{E}+08$ & $1.42 \mathrm{E}-01$ & \multirow{3}{*}{$1.40 \mathrm{E}-01$} & \multirow{3}{*}{$2.04 \mathrm{E}-03$} \\
\hline & $4.13 \mathrm{E}+08$ & $1.36 \mathrm{E}-01$ & & \\
\hline & $4.27 \mathrm{E}+08$ & $1.41 \mathrm{E}-01$ & & \\
\hline
\end{tabular}

455

By plotting mass of $\mathrm{CS}_{2}$ against time, the linear relationship is obtained.

\begin{tabular}{|c|c|c|c|c|}
\hline \multicolumn{2}{|c|}{ Slope } & \multicolumn{2}{c|}{ Intercept } & \multirow{2}{*}{ Linear Fit $-\mathrm{R}^{2}$} \\
\cline { 1 - 3 } Value & Standard Error & Value & Standard Error & \\
\hline $1.38 \mathrm{E}-01$ & $1.19 \mathrm{E}-03$ & $-4.43 \mathrm{E}-04$ & $9.57 \mathrm{E}-05$ & 0.99 \\
\hline
\end{tabular}

457

5. $\mathrm{CS}_{2}$ Generated at Different $\mathrm{pHs}$ for $0.05 \mathrm{wt} . \% \mathrm{SIBX}$ Solution for $2 \mathrm{hrs}$ at $25^{\circ} \mathrm{C}$ (for Figure 6)

\begin{tabular}{|c|c|c|c|c|}
\hline $\mathrm{pH}$ & Peak Area & Mass (mg) & Average Mass (mg) & Error \\
\hline \multirow{3}{*}{1.69} & $2.72 \mathrm{E}+08$ & $8.13 \mathrm{E}-02$ & \multirow{3}{*}{$7.22 \mathrm{E}-02$} & \multirow{3}{*}{$4.96 \mathrm{E}-03$} \\
\hline & $2.28 \mathrm{E}+08$ & $6.42 \mathrm{E}-02$ & & \\
\hline & $2.45 \mathrm{E}+08$ & $7.11 \mathrm{E}-02$ & & \\
\hline \multirow{3}{*}{2.07} & $3.45 \mathrm{E}+08$ & $1.09 \mathrm{E}-01$ & \multirow{3}{*}{$9.73 \mathrm{E}-02$} & \multirow{3}{*}{$6.46 \mathrm{E}-03$} \\
\hline & $3.10 \mathrm{E}+08$ & $9.59 \mathrm{E}-02$ & & \\
\hline & $2.87 \mathrm{E}+08$ & 8.69E-02 & & \\
\hline \multirow{3}{*}{2.18} & $3.52 \mathrm{E}+08$ & $1.12 \mathrm{E}-01$ & \multirow{3}{*}{$1.05 \mathrm{E}-01$} & \multirow{3}{*}{$4.24 \mathrm{E}-03$} \\
\hline & $3.37 \mathrm{E}+08$ & $1.06 \mathrm{E}-01$ & & \\
\hline & $3.14 \mathrm{E}+08$ & $9.75 \mathrm{E}-02$ & & \\
\hline \multirow{3}{*}{2.30} & $1.37 \mathrm{E}+08$ & $2.96 \mathrm{E}-02$ & \multirow{3}{*}{$3.57 \mathrm{E}-02$} & \multirow{3}{*}{$3.41 \mathrm{E}-03$} \\
\hline & $1.55 \mathrm{E}+08$ & $3.63 \mathrm{E}-02$ & & \\
\hline & $1.68 \mathrm{E}+08$ & 4.14E-02 & & \\
\hline \multirow{3}{*}{2.87} & $1.40 \mathrm{E}+08$ & $3.05 \mathrm{E}-02$ & \multirow{3}{*}{$3.33 \mathrm{E}-02$} & \multirow{3}{*}{$1.69 \mathrm{E}-03$} \\
\hline & $1.46 \mathrm{E}+08$ & $3.30 \mathrm{E}-02$ & & \\
\hline & $1.55 \mathrm{E}+08$ & $3.63 \mathrm{E}-02$ & & \\
\hline 3.40 & $9.21 \mathrm{E}+07$ & $1.22 \mathrm{E}-02$ & $2.47 \mathrm{E}-02$ & $6.28 \mathrm{E}-03$ \\
\hline
\end{tabular}




\begin{tabular}{|c|c|c|c|c|}
\hline & $1.38 \mathrm{E}+08$ & $2.98 \mathrm{E}-02$ & & \\
\hline & $1.44 \mathrm{E}+08$ & $3.20 \mathrm{E}-02$ & & \\
\hline \multirow{3}{*}{4.78} & $3.30 \mathrm{E}+06$ & 8.87E-04 & \multirow{3}{*}{$9.83 \mathrm{E}-04$} & \multirow{3}{*}{$5.10 \mathrm{E}-05$} \\
\hline & $4.07 \mathrm{E}+06$ & $1.06 \mathrm{E}-03$ & & \\
\hline & $3.81 \mathrm{E}+06$ & $1.00 \mathrm{E}-03$ & & \\
\hline \multirow{3}{*}{6.52} & $2.58 \mathrm{E}+06$ & $7.24 \mathrm{E}-04$ & \multirow{3}{*}{ 7.03E-04 } & \multirow{3}{*}{ 4.37E-05 } \\
\hline & $2.11 \mathrm{E}+06$ & $6.19 \mathrm{E}-04$ & & \\
\hline & $2.77 \mathrm{E}+06$ & $7.66 \mathrm{E}-04$ & & \\
\hline \multirow{3}{*}{8.03} & $1.18 \mathrm{E}+06$ & $4.10 \mathrm{E}-04$ & \multirow{3}{*}{$4.00 \mathrm{E}-04$} & \multirow{3}{*}{$7.71 \mathrm{E}-06$} \\
\hline & $1.07 \mathrm{E}+06$ & $3.85 \mathrm{E}-04$ & & \\
\hline & $1.15 \mathrm{E}+06$ & $4.04 \mathrm{E}-04$ & & \\
\hline \multirow{3}{*}{9.67} & $1.74 \mathrm{E}+06$ & $5.36 \mathrm{E}-04$ & \multirow{3}{*}{ 5.34E-04 } & \multirow{3}{*}{ 4.15E-05 } \\
\hline & $2.05 \mathrm{E}+06$ & $6.05 \mathrm{E}-04$ & & \\
\hline & $1.41 \mathrm{E}+06$ & $4.62 \mathrm{E}-04$ & & \\
\hline \multirow{3}{*}{10.87} & $7.88 \mathrm{E}+05$ & $3.21 \mathrm{E}-04$ & \multirow{3}{*}{$3.34 \mathrm{E}-04$} & \multirow{3}{*}{$1.18 \mathrm{E}-05$} \\
\hline & $7.93 \mathrm{E}+05$ & $3.22 \mathrm{E}-04$ & & \\
\hline & $9.48 \mathrm{E}+05$ & $3.57 \mathrm{E}-04$ & & \\
\hline \multirow{3}{*}{12.5} & $0.00 \mathrm{E}+00$ & $0.00 \mathrm{E}+00$ & \multirow{3}{*}{$0.00 \mathrm{E}+00$} & \multirow{3}{*}{$0.00 \mathrm{E}+0 \mathrm{c}$} \\
\hline & $0.00 \mathrm{E}+00$ & $0.00 \mathrm{E}+00$ & & \\
\hline & $0.00 \mathrm{E}+00$ & $0.00 \mathrm{E}+00$ & & \\
\hline
\end{tabular}

459

460 